\title{
KAJIAN PERANCANGAN PERMUKIMAN KAMPUNG AUR DI KOTA MEDAN (DENGAN PENDEKATAN ARSITEKTUR PERILAKU DAN LINGKUNGAN)
}

\author{
Dicky Andrea Sembiring \\ Departemen Arsitektur, Fakultas Teknik, Universitas Sumatera Utara \\ Jalan Perpustakaan Gedung J7 Kampus USU, Medan \\ (dickyandrea45@gmail.com)
}

$\begin{array}{ll}\text { Diterima } & : 15 \text { Maret } 2017 \\ \text { Disetujui } & : 24 \text { April } 2017\end{array}$

\begin{abstract}
ABSTRAK
Kampung Aur adalah salah satu pemukiman padat penduduk yang terletak di tepi Sungai Deli, Medan. Sejauh ini telah ada beberapa jenis solusi untuk masalah pemukiman padat penduduk mulai dari penggusuran paksa, pembangunan permukiman baru dalam bentuk program perbaikan datar / rusunawa dan kampung. Bisa dikatakan, pemerintah mulai menyadari bahwa masalahnya tidak bisa diatasi dengan sistem satu arah. Harus ada komunikasi dengan penghuni permukiman kumuh. Hal ini kemudian mendorong para penulis untuk membuat perencanaan permukiman Kampung Aur dengan pendekatan perilaku lingkungan untuk menjadi tesisnya. Penelitian ini bertujuan untuk menghasilkan desain permukiman yang dapat mengakomodasi aspek sosial dan budaya masyarakat melalui pendekatan perilaku lingkungan. Untuk mencapai tujuan tersebut, observasi partisipatif akan dilakukan pada setiap komunitas dominan yang ada di lokasi. Melalui pengamatan ini akan diketahui bagaimana setting lingkungan dan perilaku bekerja di Kampung Aur. Data pengaturan lingkungan dan perilaku kemudian akan diproses untuk menghasilkan kriteria desain Kampung Aur Settlement. Dari penelitian ini ditemukan bahwa ada dua suku dominan di Kampung Aur, yaitu orang Tionghoa dan Minang. Komunitas Minang lebih jauh menunjukkan karakteristik yang memiliki tingkat teritorialitas tinggi dan privasi yang rendah, sementara orang Cina justru sebaliknya. Berdasarkan karakteristik masyarakat yang ada, desing bisa diproduksi sesuai dengan perilaku masing-masing masyarakat di Kampung Aur.
\end{abstract}

Kata Kunci : Kampung Aur, Kumuh, Permukiman, Perilaku-Lingkungan

\begin{abstract}
Kampung Aur is one of the densely populated settlements situated on the banks of the Deli River, Medan. So far there have been several type of solution to the matter regarding densely populated settlements ranging from forced evictions, construction of new settlements in the form of flat / rusunawa and kampung improvement program. It can be said, the government began to realize that the problem can not be solved with one-way system. There must be communication with the slum dwellers. This then prompted the authors to make the planning of Kampung Aur settlements with environmental-behavioral approach to be the title of his thesis. This study aims to produce a design of settlement which can accommodate social and cultural aspects of society through environmental behavior approach. To achieve these objectives, participatory observation will be conducted on each dominant communities that exist on the site. Through these observations it will be known how the environmental setting and behavior setting works in Kampung Aur. The data of environmental setting
\end{abstract}


and behavior setting will then be processed to produce design criteria of Kampung Aur Settlement. From this research it was found that there are two dominant tribe in Kampung Aur, the Chinese and Minang. Minang communities further demonstrate characteristics that have a high degree of territoriality and low privacy, while Chinese are just the opposite. Based on the characteristics of the existing society, a desing can be produced in accordance with the behavior of each communities in Kampung Aur

Keywords: Aur Settlement, Environmental Behavior, Slum

\section{Pendahuluan}

Permukiman Kampung Aur merupakan salah satu permukiman padat penduduk yang terletak di bantaran Sungai Deli, Kelurahan Kampung Aur, Medan. Jika berbicara mengenai permukiman Kampung Aur, maka pandangan umum yang muncul adalah permukiman padat penduduk yang tidak teratur, bangunan semi permanen, kurang memperhatikan kebersihan serta legalitas bangunan yang masih dipertanyakan.

Munculnya permukiman kumuh di kawasan pusat kota seperti ini sebenarnya tidak hanya terjadi di Kota Medan saja. Kasus seperti ini juga terjadi hampir di seluruh kotakota besar yang ada di Indonesia. Sebagai contohnya dapat dlihat pada permukiman kumuh sepanjang aliran Sungai Ciliwung di Jakarta, permukiman kumuh di bantaran Sungai Code di Yogyakarta, permukiman kumuh di bantaran Sungai Musi di Palembang dan banyak contoh sejenis lainnya.

Sejauh ini sudah ada beberapa bentuk penyelesaian yang dilaksanakan terkait masalah ini. Mulai dari hal yang sifatnya sangat teknis seperti penggusuran dan pembangunan rusun/rusunawa di daerah baru, kemudian mulai menerapkan prinsip tri-daya (sosial, ekonomi dan fisik-lingkungan) pada program KIP di tahun 1969, hingga pada rencana terbaru pemerintah yang sudah memberikan 3 (tiga) kemungkinan penyelesaian terhadap masalah ini yaitu melalui pelayakan permukiman, peremajaan (perbaikan kawasan dimana masyarakat harus pindah secara temporer) dan permukiman kembali (disini masyarakat akan direlokasi menuju permukiman baru yang telah dibangun). Dapat dikatakan, pemerintah mulai menyadari bahwa permasalahan permukiman kumuh ini tidak dapat diselesaikan dengan sistem satu arah. Harus ada komunikasi dengan penduduk permukiman kumuh. Banyak aspek yang harus menjadi perhatian terutama aspek sosial-budaya masyarakat (hubungan masyarakat dengan lingkungannya).

Hal ini juga sejalan dengan apa yang disampaikan oleh Rapoport (1977) bahwa hubungan antara manusia dan lingkungan sebenarnya tidaklah bersifat mekanistis belaka. Hubungan ini penuh makna, simbol dan norma-norma, merupakan kewajiban kita untuk memahami makna-makna tersebut, agar proses penciptaan lingkungan selanjutnya tidak terjebak dalam proses besar dehumanisasi yang sedang berlangsung.

Kondisi ini jugalah yang terjadi pada permukiman Kampung Aur. Berdasarkan observasi awal yang dilakukan, dapat dilihat kerumitan masalah yang ada di sini. Mulai dari masalah fisik seperti ketidaklayakan fisik bangunan dan sanitasi, tingkat kepadatan yang terlalu tinggi, hingga masalah sosial budaya masyarakat seperti kebiasaan masyarakat setempat, kedekatan dengan tempat kerja, dan hal lainnya yang menyebabkan masyarakat merasa sudah nyaman dengan tempat tinggal mereka.

Melihat hal ini, maka perancangan harus diselesaikan dengan pendekatan yang berbasis pada perilaku masyarkat dan lingkungannya. Haryadi dan Setiawan (2014) menganjurkan penyelesaian masalah permukiman kumuh di perkotaan sebaiknya menjadi salah satu kajian utama dalam arsitektur perilaku-lingkungan, mengingat kompleksnya hubungan antara aspek sosial-budaya masyarakat dengan lingkungan pada kasus rumah susun perkotaan. Arsitektur perilaku-lingkungan itu sendiri merupakan arsitektur yang mengkaji bagaimana hubungan masyarakat terhadap lingkungannya yang didasarkan pada kognisi masing-masing indvidu. Dengan arsitektur perilaku akan diketahui seting lingkungan yang diinginkan oleh masyarakat dan peta-peta perilaku yang dapat dijadikan sebagai kriteria dalam menghasilkan rancangan yang lebih berdasarkan kepada pengguna bangunan. 


\section{Kajian Perancangan Pemukiman Kampung Aur di Kota Medan (Dengan Pendekatan Arsitektur Perilaku dan Lingkungan)}

Berdasarkan penejelasan yang sudah dipaparkan maka yang menjadi pokok permasalahan utama dalam penelitian antara lain : (1) Mengetahui setting lingkungan permukiman yang diinginkan oleh masyarakat, (2) Mengetahui setting perilaku masyarakat, (3) Merancang permukiman Kampung Aur berdasarkan setting lingkungan dan setting perilaku yang telah diperoleh.

\section{Metodologi Penelitian}

Adapun metode penelitian yang dipergunakan dibuat berdasarkan proses riset dan perencanaan lingkungan (RPL) yang dikemukakan oleh Cherulnik (Haryadi dan Setiawan, 2014). Namun akan dilakukan pengolahan lebih lanjut oleh penulis sesuai dengan kebutuhan dari objek yang diteliti, dapat dilihat pada tabel 1 sebagai berikut :

Tabel 1 Proses Riset dan Perencanaan Lingkungan (RPL)

\begin{tabular}{|c|c|}
\hline $\begin{array}{l}\text { Riset dan } \\
\text { Perencanaan } \\
\text { Lingkungan } \\
\text { (Cherulnik) }\end{array}$ & $\begin{array}{l}\text { Tahapan Penelitian } \\
\text { yang Dilaksanakan }\end{array}$ \\
\hline $\begin{array}{l}\text { Analisis latar } \\
\text { belakang dari acting }\end{array}$ & $\begin{array}{l}\text { Pengumpulan Data } \\
\text { Umum }\end{array}$ \\
\hline $\begin{array}{l}\text { Tahapan } \\
\text { pengumpulan data } \\
\text { berupa data } \\
\text { kependudukan, } \\
\text { sosial, } \\
\text { ekonomi,sejarah, } \\
\text { budaya, dan kondisi } \\
\text { lingkungan } \\
\text { Kampung Aur }\end{array}$ & $\begin{array}{l}\text { Data yang } \\
\text { dikumpulkan berupa } \\
\text { data sosial, demografi, } \\
\text { ekonomi penduduk } \\
\text { dan data lingkungan } \\
\text { serta data unit hunian }\end{array}$ \\
\hline $\begin{array}{l}\text { Tujuan-tujuan } \\
\text { perilaku untuk } \\
\text { perencanaan } \\
\text { perancangan }\end{array}$ & $\begin{array}{l}\text { Pengumpulan Data } \\
\text { Perilaku }\end{array}$ \\
\hline $\begin{array}{l}\text { Tahapan } \\
\text { pengumpulan data } \\
\text { berupa data perilaku } \\
\text { masyarakat }\end{array}$ & $\begin{array}{l}\text { Data perilaku yang } \\
\text { dihasilkan adalah } \\
\text { berupa data deskripsi } \\
\text { ruang dan data } \\
\text { deskripsi perilaku }\end{array}$ \\
\hline $\begin{array}{l}\text { Hubungan } \\
\text { lingkungan } \\
\text { perilaku } \\
\text { relevan }\end{array}$ & $\begin{array}{l}\text { Yang dapat membantu } \\
\text { dalam }\end{array}$ \\
\hline
\end{tabular}

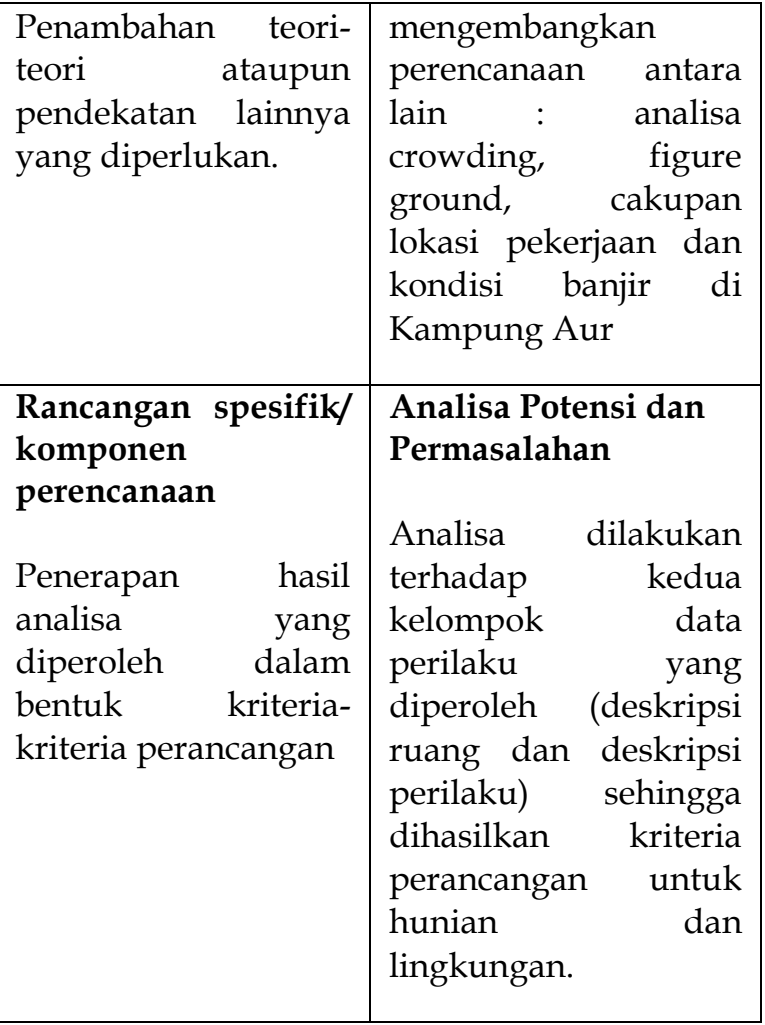

Yang menjadi populasi penelitian adalah etnis masyarakat yang ada di permukiman Kampung Aur, sedangkan sampelnya akan diambil dengan metode purposive sampling dimana sampel akan diambil dari masingmasing keluarga dari setiap etnis dengan tipe hunian yang berbeda antara satu dengan yang lain.

Untuk lebih jelasnya metode penelitian yang dilaksanakan dapat dilihat dalam gambar 1 berikut :

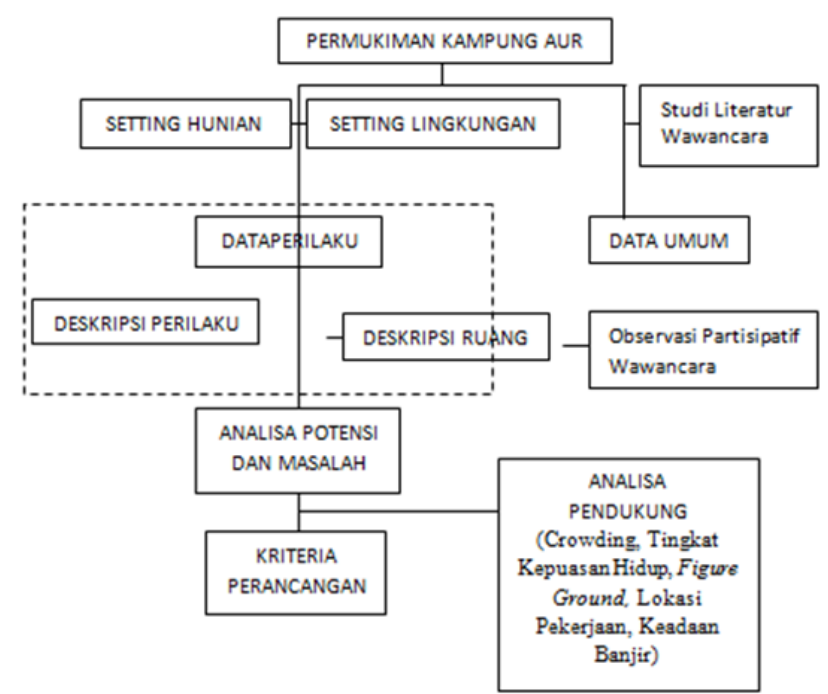


Gambar 1 Tahapan Metodologi Penelitian

\section{Hasil dan Pembahasan}

\subsection{Tinjauan Kawasan Permukiman}

\section{Kampung Aur}

Permukiman Kampung Aur merupakan salah satu lingkungan (lingkungan IV) dari Kelurahan Aur, Kecamatan Medan Maimun, Kota Medan. Permukiman ini terletak di antara simpang Jalan Letjen Suprapto dan Jalan Brigjen Katamso, dapat dilihat pada gambar 2.

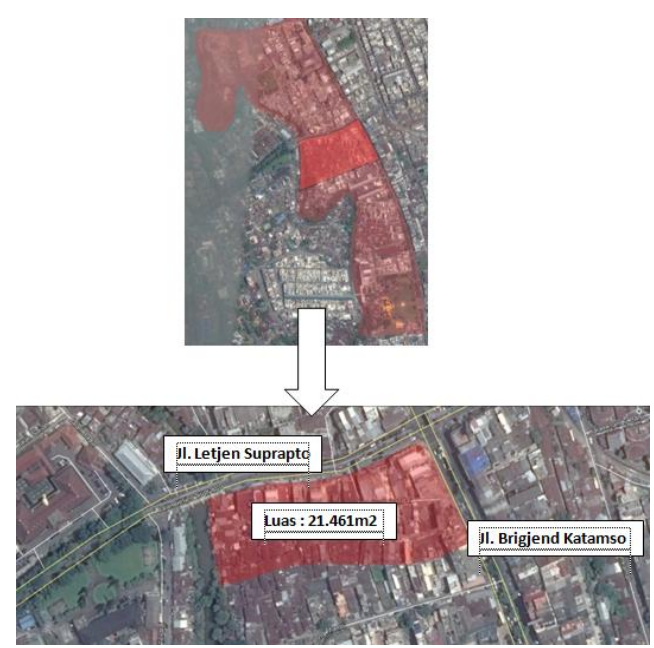

\section{Gambar 2 Peta Lokasi Kampung Aur}

Secara umum diketahui bahwa permukiman Kampung Aur didominasi oleh dua (2) etnis utama yaitu : etnis Minang dan etnis Cina. Seperti dapat dilihat pada gambar 3.

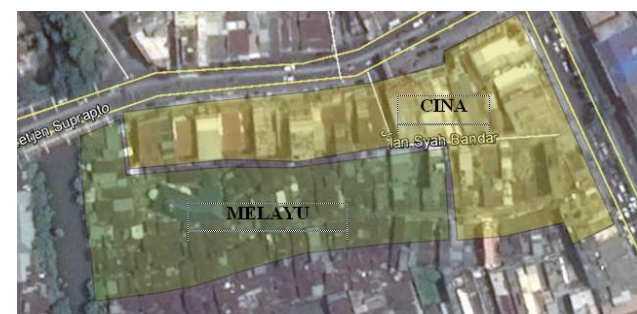

Gambar 3 Pembagian Kawasan Hunian Berdasarkan Etnis

Permukiman etnis Minang terbagi menjadi dua bagian besar yaitu rumah tinggal yang berfungsi sebagai rumah tinggal saja dan rumah tinggal yang sekaligus berfungsi sebagai tempat usaha. Sebanyak $74,07 \%$ hunian yang ada di Kampung Aur merupakan milik dari penduduk etnis Minang dan sebesar 91,42\% penduduk Kampung Aur merupakan penduduk etnis Minang.

Untuk penduduk etnis Cina, tipologi huniannya terbagi menjadi tiga (3) bagian yaitu ruko, hunian saja serta hunian yang berfungsi ganda sebagai tempat usaha. Sebanyak 24,6\% hunian yang ada di Kampung Aur dimiliki oleh penduduk etnis Cina dan sebesar 7,8\% penduduk Kampung Aur beretnis Cina.

Disamping kedua etnis di atas juga terdapat etnis penduduk lainnya seperti penduduk etnis Manado, Tamil dan Nias, namun jumlahnya sangat sedikit, dimana masing-masing etnis terdiri dari satu (1) keluarga saja, sehingga tidak memiliki pengaruh yang begitu signifikan untuk dijadikan sampel dari objek penelitian.

Selain melihat etnis yang dominan serta masing-masing tipologi huniannya, dari hasil observasi yang dilakukan juga ditemui ada beberapa komponen lingkungan yang dianggap penting dan langsung berdampak terhadap perilaku masyarkat di Kampung Aur. Adapun komponen lingkungan yang dimaksud antara lain : (1) Warung yang memiliki berbagai fungsi antara lain sebagai tempat berkumpul masyarakat; (2) Ruang bermain anak; (3) Sisa ruang antar bangunan yang dijadikan sebagai tempat berinteraksi; (4) Pelataran mesjid; (5) Tempat jajanan malam; (6) Bantaran Sungai; (7) Jalan yang juga memiliki fungsi lain seperti tempat terjadinya interaksi dan kegiatan ekonomis. Untuk lebih lengkapnya dapat dilihat pada gambar 4 .
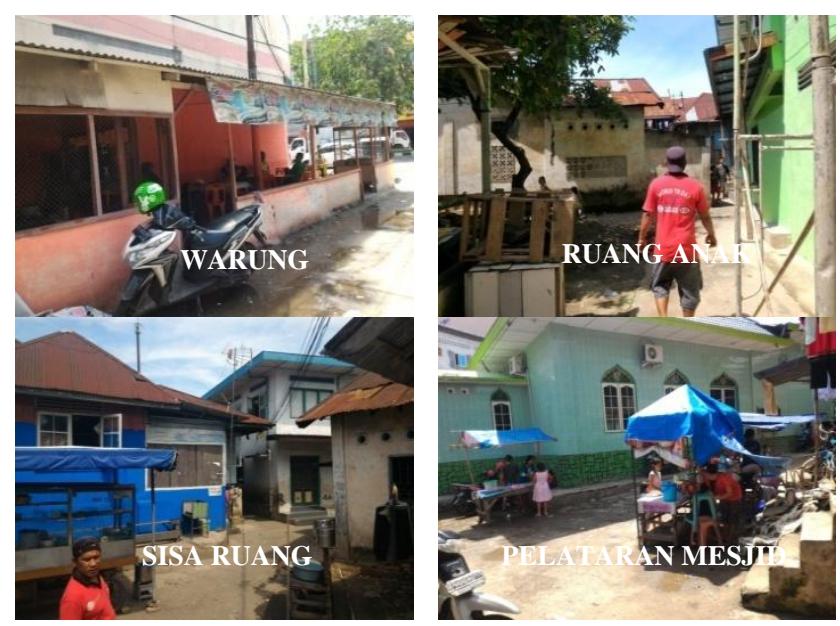


\section{Kajian Perancangan Pemukiman Kampung Aur di Kota Medan (Dengan Pendekatan Arsitektur Perilaku dan Lingkungan)}
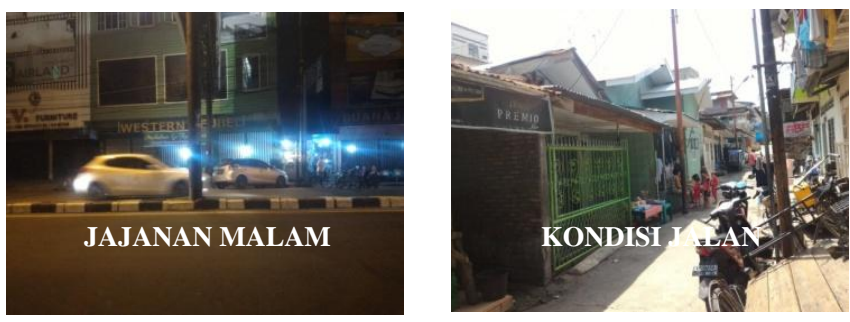

\section{Gambar 4 Komponen Lingkungan di Permukiman Kampung Aur}

\subsection{Eksplorasi Perilaku Masyarakat Etnis Minang pada Unit Huniannya \\ Eksplorasi perilaku masyarakat etnis} Minang pada huniannya dilakukan terhadap sepuluh (10) keluarga sebagai sampelnya. Namun berikut akan dijelakan perilaku pada salah satu keluarga saja sebagai pembandingnya (tabel 2).

\section{Tabel 2 Keluarga Etnis Minang (Surya} Sumardi)

\begin{tabular}{|l|l|}
\hline $\begin{array}{l}\text { Nama kepala } \\
\text { keluarga }\end{array}$ & $\begin{array}{l}\text { Surya Sumardi, Nasrul dan } \\
\text { Dodi }\end{array}$ \\
\hline Fungsi Hunian & Rumah Tinggal (2 lantai) \\
\hline $\begin{array}{l}\text { Jumlah anggota } \\
\text { keluarga }\end{array}$ & $\begin{array}{l}\text { 9 orang (multi famili) } \\
\text { Nasrul (47 tahun) - 3 orang (1 } \\
\text { anak perempuan berumur 20 } \\
\text { tahun, suami dan istri) } \\
\text { Surya Sumardi (38 tahun) - 5 } \\
\text { orang (1 anak perempuan umur } \\
4 \text { tahun, 2 anak laki-laki umur 7 } \\
\text { tahun dan 13 tahun, suami dan } \\
\text { istri) } \\
\text { Dodi (31 tahun) - belum } \\
\text { berkeluarga }\end{array}$ \\
\hline Lokasi & \multicolumn{1}{|l|}{} \\
\hline
\end{tabular}

\begin{tabular}{|c|c|}
\hline \multirow[t]{3}{*}{ Pekerjaan } & $\begin{array}{l}\text { Nasrul dan istri bekerja sebagai } \\
\text { pedagang musiman dan pada } \\
\text { saat dilakukan pengamatan } \\
\text { sedang menekuni pekerjaan } \\
\text { sebagai pembuat gula merah. } \\
\text { Anak perempuannya bekerja } \\
\text { sebagai pegawai di salah satu } \\
\text { supermarket di dekat Kampung } \\
\text { Aur. }\end{array}$ \\
\hline & $\begin{array}{l}\text { Surya Sumardi bekerja sebagai } \\
\text { pegawai keamanan di di } \\
\text { perusahaan swasta di dekat } \\
\text { lokasi penelitian dan isterinya } \\
\text { sebagai ibu rumah tangga } \\
\text { sekaligus menjual kartu untuk } \\
\text { kuota internet. } 2 \text { anak laki- } \\
\text { lakinya masih bersekolah di } \\
\text { tingkat SD dan SMP sedangkan } \\
\text { anak perempuannya belum } \\
\text { bersekolah. }\end{array}$ \\
\hline & $\begin{array}{l}\text { Dodi bekerja sebagai pekerja } \\
\text { serabutan. Pada saat penelitian } \\
\text { dilakukan sedang bekerja } \\
\text { sebagai pekerja bangunan di RT } \\
\text { sebelah (masih di Kelurahan } \\
\text { Aur juga) }\end{array}$ \\
\hline $\begin{array}{l}\text { Riwayat } \\
\text { Keluarga }\end{array}$ & $\begin{array}{lr}\text { Rumah ini merupakan rumah } \\
\text { peninggalan orang tua terhadap } \\
\text { ketiga anaknya (istri } & \text { Surya } \\
\text { Sumardi, Nasrul dan } & \text { Dodi) } \\
\text { yang bersuku Melayu. } & \\
\text { Nasrul merupakan anak } \\
\text { pertama diikuti istri Surya } \\
\text { Sumardi dan Dodi. }\end{array}$ \\
\hline
\end{tabular}

Hunian keluarga Surya Sumardi merupakan hunian dua (2) lantai dimana pada bagian depannya (ruang tamu) juga dipergunakan sebagai tempat penjualan pulsa. Untuk membantu visualisasi akan unit huniannya dapat dilihat pada gambar 5 .

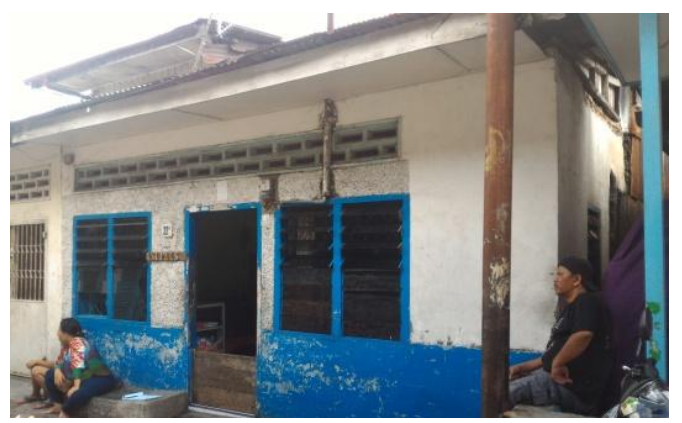




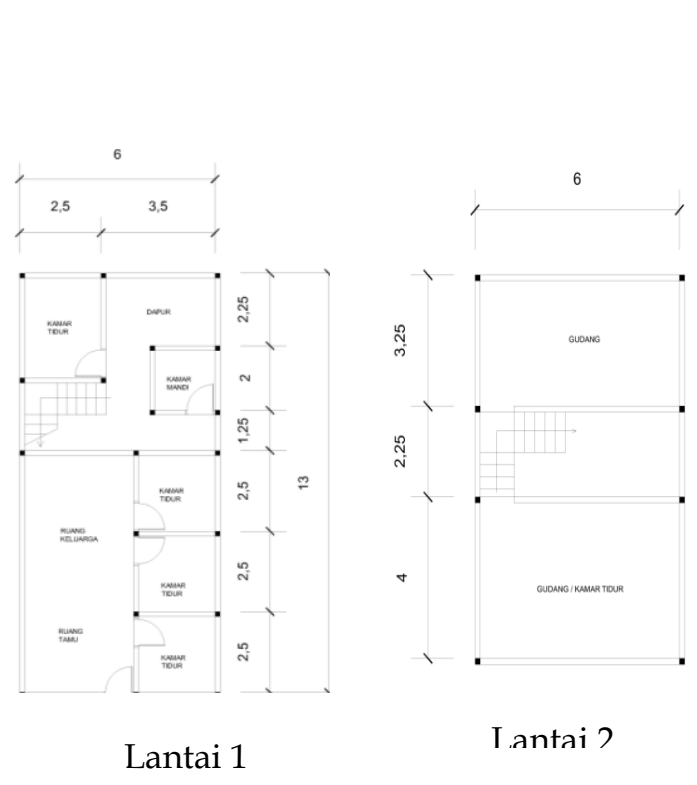

\section{Gambar 5 Tampak dan Denah Hunian Keluarga Surya Sumardi}

Dari hasil observasi partisipatif yang dilakukan, didapatkan deskripsi ruang dan deskripsi perilaku yang dapat dilihat pada tabel 3 dan tabel 4 :

Tabel 3 Deskripsi Ruang Keluarga Surya Sumardi

\begin{tabular}{|l|}
\hline \multicolumn{2}{|c|}{ Deskripsi Ruang } \\
\hline Ukuran dan Bentuk Ruang \\
Pada ruang tamu/keluarga, kamar tidur dan \\
dapur pada umumnya sifatnya fleksibel \\
mengikuti kebutuhan penghuni rumah, teras \\
sifatnya terbuka dan kamar mandi umumnya \\
kurang memenuhi standar. Sedangkan untuk \\
penambahan ruang biasanya sejalan dengan \\
pertambahan jumlah keluarga dan biasanya \\
menggunakan bahan semi permanen. \\
\hline Perletakan Perabotan \\
Pada ruang tamu/ruang keluarga, dapur dan \\
kamar mandi perletakan perabotan fleksibel \\
dan cenderung tidak teratur. Hanya kamar \\
yang memiliki pengaturan perabotan tertentu \\
\hline Warna \\
Pemilihan warna cerah untuk bagian luar dan \\
dalam ruangan, kecuali kamar tidur biasanya \\
memiliki warna putih \\
\hline Temperatur \\
Kondisi penghawaan secara alami minim \\
\hline Pencahayaan \\
Kondisi pencahayaan secara alami minim \\
\hline Kebisingan \\
Tidak ada perlakuan khusus untuk masalah \\
\hline
\end{tabular}

kebisingan

Tabel 4 Deskripsi Perilaku Keluarga Surya Sumardi

\begin{tabular}{|l|}
\hline \multicolumn{2}{|c|}{ Deskripsi Perilaku } \\
\hline Pola Aktivitas Penghuni Rumah \\
Penghuni pada umumnya memiliki pekerjaan \\
tidak tetap dan cenderung berubah-ubah. Hal \\
ini berpengaruh secara langsung terhadap \\
perubahan fungsi ruang serta perletakan \\
perabotan di tiap ruangan
\end{tabular}

\section{Privasi / Teritori}

Pada masyarakat Minang pada umumnya privasi masing-masing unit hunian hanya terdapat pada bagian kamar tidur masingmasing, sedangkan untuk ruang tamu dan ruang lainnya sifatnya biasanya berada pada ruang publik ataupun semi publik/privat.

Hal ini menyebabkan rasa kebersamaan dan rasa saling memiliki yang tinggi. Kemudahan dalam melaksanakan kegiatan yang sifatnya kegiatan bersama.

\section{Aktivitas Sosial di Teras Rumah}

Teras rumah pada umumnya digunakan sebagai tempat bersosialisasi oleh ibu-ibu rumah tangga pada sore hari

\section{Penambahan Ruang}

Penambahan ruang didasarkan pada penambahan jumlah anggota keluarga yang sudah berkeluarga

\section{Penentuan Jumlah Kamar Tidur}

Selain jumlah anggota keluarga yang sudah memiliki keluarga sendiri, pertambahan jumlah kamar juga dipengaruhi oleh ada atau tidaknya anak perempuan yang sudah dewasa.

\subsection{Eksplorasi Perilaku Masyarakat Etnis Cina pada Unit Huniannya \\ Eksplorasi perilaku masyarakat etnis Cina pada huniannya dilakukan terhadap delapan (8) keluarga sebagai sampelnya. Namun berikut akan dijelakan perilaku pada salah satu keluarga saja sebagai pembandingnya (tabel 5).}


Tabel 5 Keluarga Etnis Ci na (Eni Tenggara)

\begin{tabular}{|c|c|}
\hline $\begin{array}{l}\text { Nama kepala } \\
\text { keluarga }\end{array}$ & Eni Tenggara \\
\hline Fungsi Hunian & Rumah Tinggal (1 lantai) \\
\hline $\begin{array}{l}\text { Jumlah anggota } \\
\text { keluarga }\end{array}$ & $\begin{array}{l}5 \text { orang (single famili) } \\
\text { Suami - sudah meninggal } \\
\text { dunia } \\
\text { Isteri ( } 57 \text { tahun) - Eni } \\
\text { Tenggara } \\
\text { Anak Perempuan (18 tahun) } \\
\text { Anak laki-laki I (30 tahun) - } \\
\text { sudah berkeluarga dan } \\
\text { tinggal di luar kota } \\
\text { Anak laki-laki II (26 tahun) - } \\
\text { sudah berkeluarga dan } \\
\text { tinggal di luar kota. }\end{array}$ \\
\hline Lokasi & \\
\hline Pekerjaan & $\begin{array}{l}\text { Eni Tenggara } r \text { bekerja } \\
\text { sebagai ibu rumah tangga, } \\
\text { dimana sekarang masalah } \\
\text { keuangan sudah banyak } \\
\text { dibantu oleh anak laki-laki } \\
\text { yang sudah bekerja. } \\
\text { Sebelumnya bersama suami } \\
\text { berdagang di pajak sambas } \\
\text { di dekat lokasi (membuka } \\
\text { kios). }\end{array}$ \\
\hline & $\begin{array}{l}\text { Anak Perempuan belajar di } \\
\text { tingkat pendidikan Sekolah } \\
\text { Menegah Atas (SMA) }\end{array}$ \\
\hline $\begin{array}{l}\text { Riwayat } \\
\text { Keluarga }\end{array}$ & $\begin{array}{l}\text { Rumah ini merupakan } \\
\text { rumah yang dibeli oleh Eni } \\
\text { Tenggara dan suaminya } \\
\text { pada sekitar tahun } 2003 \text {. } \\
\text { Sebelumnya menyewa } \\
\text { rumah juga tidak jauh dari } \\
\text { lokasi sekarang }\end{array}$ \\
\hline
\end{tabular}

Hunian keluarga Eni Tenggara merupakan hunian satu (1) lantai. Hanya berfungsi sebagai rumah tinggal saja dan hanya dihuni oleh dua
(2) orang. Untuk membantu visualisasi akan unit huniannya dapat dilihat pada gambar 6 .
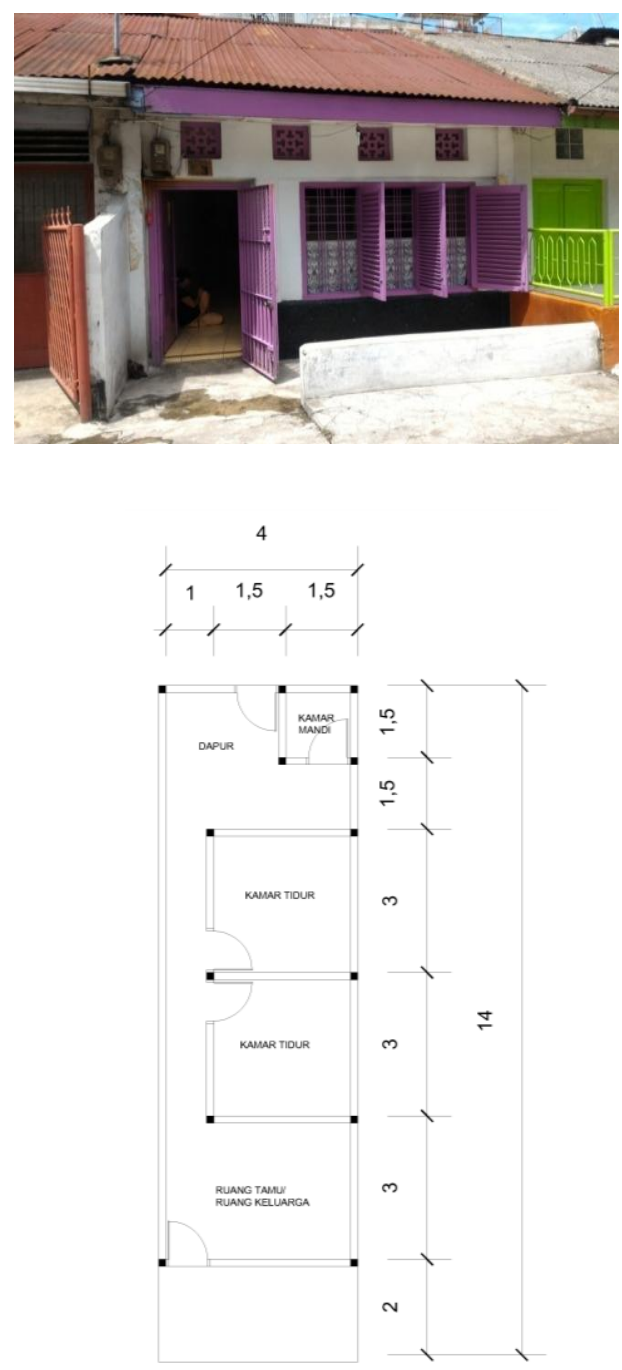

\section{Gambar 6 Tampak dan Denah Hunian Keluarga Enit Tenggara}

Dari hasil observasi partisipatif yang dilakukan, didapatkan deskripsi ruang dan deskripsi perilaku yang dapat dilihat pada tabel 6 dan tabel 7 :

\section{Tabel 6 Deskripsi Ruang Keluarga Enit Tenggara}

\section{Ukuran dan Bentuk Ruang}

Bentuk dan ukuran ruang cukup fleksibel, namun sudah mempunyai fungsi yang tetap, artinya ruang tamu akan berfungsi sebagai ruang tamu dan tidak akan digunakan sebagai ruang tidur tambahan ,ruang berjualan ataupun ruang lainnya. 


\begin{tabular}{|l|}
\hline Perletakan Perabotan \\
Jika dilihat dari pengamatan yang sudah \\
dilakukan, perletakan perabot terkadang \\
masih kurang beraturan namun tidak sejauh \\
seperti yang terjadi pada pemukiman etnis \\
Minang \\
\hline Warna \\
Pemilihan warna cerah untuk bagian luar dan \\
dalam ruangan, kecuali kamar tidur biasanya \\
memiliki warna putih \\
\hline Temperatur \\
Kondisi penghawaan secara alami sedang \\
\hline \begin{tabular}{l} 
Pencahayaan \\
Kondisi pencahayaan secara alami sedang \\
\hline Kebisingan \\
Tingkat kebisingan cukup rendah, hal ini \\
terkait dengan privasi yang tinggi. Ini juga \\
tercermin dalam penggunaan material \\
permanen dalam penyekat ruangan
\end{tabular} \\
\hline
\end{tabular}

Tabel 7 Deskripsi Perilaku Keluarga Enit Tenggara

\begin{tabular}{|l|}
\hline \multicolumn{2}{|c|}{ Deskripsi Perilaku } \\
\hline Pola Aktivitas Penghuni Rumah \\
Penghuni pada umumnya memiliki pekerjaan \\
tetap ataupun memiliki aktivitas yang sudah \\
tetap sepanjang hari, ini akan langsung \\
berpengaruh terhadap aktivitas yang terjadi \\
di dalam ruangan
\end{tabular}

\section{Privasi / Teritori}

Pada masyarakat etnis Cina privasi bisa dikatakan sangat tinggi. Sangat tidak suka jika ruang pribadinya dimasuki oleh orang lain.Hal ini menyebabkan rasa kebersamaan yang kurang serta interaksi dengan masyarakat etnis lain yang rendah.

\section{Interaksi Sosial yang Sangat Minim}

Interaksi sosial sangat minim terjadi dan hanya mungkin terjadi pada bagian teras depan rumah.

\section{Kebiasaan Menanam Tanaman}

Kebanyakan masyarakat etnis Cina menyempatkan diri untuk menanam dan merawat tanaman yang memang sengaja ditata di bagian depan teras rumah

\subsection{Eksplorasi Perilaku Masyarakat}

Kampung Aur terhadap Lingkungannya

Untuk komponen lingkungan yang sudah disampaikan sebelumnya, berdasarkan hasil observasi partisipatif yang dilakukan, maka didapatkan bentuk-bentuk aktivitas yang biasanya terjadi pada komponen-komponen lingkungan tersebut, dapat dilihat pada tabel 8 :

\section{Tabel 8 Deskripsi Aktivitas lingkungan}

\begin{tabular}{|c|c|}
\hline $\begin{array}{c}\text { Komponen } \\
\text { Lingkungan }\end{array}$ & Aktivitas yang Diwadahi \\
\hline Warung & $\begin{array}{l}\text { sebagai warung tempat } \\
\text { menjual makanan dan } \\
\text { minuman } \\
\text { - tempat terjadinya interaksi } \\
\text { sosial penduduk etnis } \\
\text { Minang laki-laki dewasa } \\
\text { - penanda masuk ke } \\
\text { Kampung Aur } \\
\text { - sebagai pos penjagaan } \\
\text { terhadap kemanan di } \\
\text { Kampung Aur (pos ronda } \\
\text { / persinggahan ronda } \\
\text { malam) }\end{array}$ \\
\hline $\begin{array}{l}\text { Ruang } \\
\text { Terbuka } \\
\text { Anak }\end{array}$ & $\begin{array}{l}\text { ruang terbuka ini adalah } \\
\text { akan dibuat langsung } \\
\text { berhubungan dengan } \\
\text { tempat belajar mengaji, } \\
\text { yang juga langsung } \\
\text { berhubungan dengan } \\
\text { pelataran Mesjid. Dengan } \\
\text { menghidupkan ruang } \\
\text { terbuka anak ini juga } \\
\text { diharapkan dapat } \\
\text { mengurangi kemungkinan } \\
\text { timbulnya patologi sosial } \\
\text { yang berlokasi tidak jauh } \\
\text { dari ruang terbuka ini } \\
\text { melalui sistem "natural } \\
\text { surveillance" }\end{array}$ \\
\hline $\begin{array}{l}\text { Ruang } \\
\text { Terbuka } \\
\text { Umum }\end{array}$ & $\begin{array}{ll}\text { - } & \text { sebagai tempat PKL } \\
\text { berjualan } \\
\text { sebagai tempat berkumpul } \\
\text { dan terjadinya interaksi } \\
\text { sosial penduduk etnis } \\
\text { Minang di Kampung Aur } \\
\text { - sebagai "pengawas" } \\
\text { terhadap kegiatan yang } \\
\text { terjadi di ruang terbuka } \\
\text { anak, mengingat letaknya } \\
\text { yang langsung berbatasan }\end{array}$ \\
\hline Pelataran & $\begin{array}{lll}\text { - } & \text { ruang } & \text { terbuka ini } \\
& \text { digunakan oleh PKL untuk }\end{array}$ \\
\hline
\end{tabular}




\begin{tabular}{|c|c|}
\hline Mesjid & 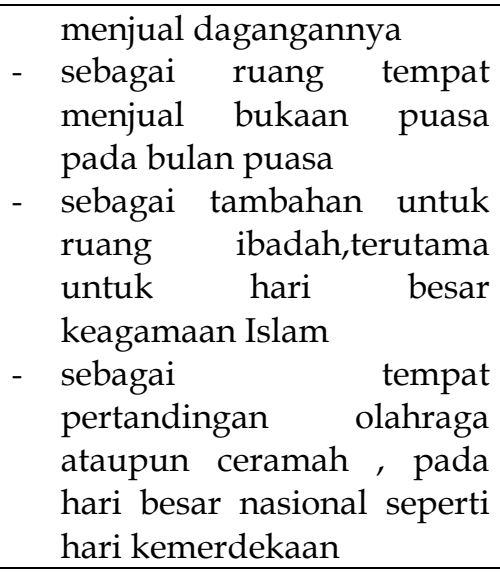 \\
\hline $\begin{array}{l}\text { Tempat } \\
\text { Cuci } \\
\text { Bersama / } \\
\text { Bantaran } \\
\text { Sungai }\end{array}$ & $\begin{array}{l}\text { dapat dikatakan bahwa } \\
\text { pemanfaatan fasilitas ini } \\
\text { hampir bisa dikatakan } \\
\text { sama sekali tidak efektif. } \\
\text { Penggunanya hanya } \\
\text { berasal dari rumah } \\
\text { penduduk yang ada di } \\
\text { bantaran sungai. Sebagian } \\
\text { besar penduduk tidak lagi } \\
\text { menggunakannya } \\
\text { pembongkaran terhadap } \\
\text { beberapa rumah yang } \\
\text { letaknya langsung di tepi } \\
\text { bantaran sungai } \\
\text { dikarenakan crowding } \\
\text { yang terlalu tinggi, rumah } \\
\text { yang tidak standar dan } \\
\text { seringnya terjadi banjir } \\
\text { membangun tanggul di } \\
\text { sepanjang bantaran sungai } \\
\text { tanggul ini nantinya } \\
\text { diharapakan juga dapat } \\
\text { digunakan sebagai tempat } \\
\text { "menonton" terhadap } \\
\text { kegiatan y yang } \\
\text { dilaksanakan di Sungai } \\
\text { Deli. Beberapa tahun lalu } \\
\text { dapat dikatakan bahwa } \\
\text { cukup banyak terjadi } \\
\text { kegiatan yang melibatkan } \\
\text { Sungai Deli ini, seperti } \\
\text { lomba kayak, panjat pinang } \\
\text { di sungai dll yang } \\
\text { terutama dilaksanakan } \\
\text { pada hari kemerdekaan RI. } \\
\text { Kegiatan-kegiatan seperti } \\
\text { ini diharapkan dapat } \\
\text { muncul kembali sehingga } \\
\text { muncul rasa menghargai } \\
\text { masyarakat terhadap } \\
\text { Sungai Deli }\end{array}$ \\
\hline
\end{tabular}

\begin{tabular}{|l|l|}
\hline $\begin{array}{l}\text { Tempat } \\
\text { Jajanan }\end{array}$ & $\begin{array}{l}\text { Malam } \\
\text { jajanan malam di pelataran } \\
\text { ruko di Jalan Brigjend } \\
\text { Katamso }\end{array}$ \\
\hline Jalan (Sirkulasi) \\
\hline $\begin{array}{l}\text { Jalan } \\
\text { dengan } \\
\text { tingkat } \\
\text { keramaian } \\
\text { tinggi }\end{array}$ & $\begin{array}{l}\text { sebagai tempat terjadinya } \\
\text { interaksi sosial di } \\
\text { masyarakat } \\
\text { sebagai tempat terjadinya } \\
\text { kegiatan ekonomi }\end{array}$ \\
\hline $\begin{array}{l}\text { Jalan } \\
\text { dengan } \\
\text { tingkat } \\
\text { keramaian } \\
\text { sedang }\end{array}$ & $\begin{array}{l}\text { menimbulkan interaksi } \\
\text { antar penduduk etnis Cina } \\
\text { dengan penduduk sekitar }\end{array}$ \\
\hline $\begin{array}{l}\text { Jalan } \\
\text { dengan } \\
\text { tingkat } \\
\text { keramaian } \\
\text { rendah }\end{array}$ & $\begin{array}{l}\text { menerapkan kriteria desain } \\
\text { yang dapat mencegah } \\
\text { terjadinya tindak kriminal }\end{array}$ \\
\end{tabular}

3.5 Analisa Pendukung (Crowding, Tingkat Kepadatan, Kepuasan Hidup, Cakupan Lokasi Pekerjaan dan Keadaan Banjir)

Analisa pendukung ini berfungsi untuk memberikan input tambahan terhadap data perilaku dan data ruang yang sudah dikumpulkan. Dengan adanya analisa pendukung ini, dapat diketahui bagaimana tipologi bangunan yang tepat untuk permukiman Kampung Aur, Tingkat ketergantungan pekerjaan terhadap lokasi tempat tinggal, Keadaan banjir dan bantaran sungai, serta adapatasi masyarakat terhadap kehidupan di Kampung Aur. Hasil analisa pendukung ini dapat dilihat dengan jelas pada tabel 9:

Tabel 9 Analisa Pendukung

\begin{tabular}{|c|c|}
\hline $\begin{array}{c}\text { Analisa } \\
\text { Pendukung }\end{array}$ & Hasil Analisa \\
\hline Crowding & $\begin{array}{l}\text { - } \text { Tidak banyak indikasi } \\
\text { munculnya penyakit psikis } \\
\text { dan fisik } \\
\text { - Ada indikasi munculnya } \\
\text { patologi sosial terutama di } \\
\text { daerah bantaran sungai dan } \\
\text { daerah yang sepi (belakang } \\
\text { ruko Letjen Suprapto) } \\
\text { - Ada indikasi munculnya } \\
\text { tingkah laku sosial negatif }\end{array}$ \\
\hline
\end{tabular}




\begin{tabular}{|c|c|}
\hline & $\begin{array}{l}\text { terutama di daerah bantaran } \\
\text { sungai }\end{array}$ \\
\hline $\begin{array}{l}\text { Tingkat } \\
\text { Kepuasan } \\
\text { Hidup }\end{array}$ & $\begin{array}{l}\text { Sebagian besar penduduk } \\
\text { merasa cukup puas tinggal } \\
\text { di Kampung Aur }\end{array}$ \\
\hline $\begin{array}{l}\text { Figure } \\
\text { Ground }\end{array}$ & $\begin{array}{lr}\text { - Walaupun } & \text { termasuk } \\
\text { permukiman yang padat, } & \text { y } \\
\text { tetapi masih dimungkinkan } \\
\text { untuk } & \text { dilakukan } \\
\text { peningkatan } & \text { bangunan } \\
\text { hingga menjadi } 2 \text { atau } 3 \\
\text { lantai. Belum diperlukan } \\
\text { adanya bangunan massal } \\
\text { vertikal dalam waktu dekat } \\
\text { ini. }\end{array}$ \\
\hline $\begin{array}{l}\text { Cakupan } \\
\text { Lokasi } \\
\text { Pekerjaan }\end{array}$ & $\begin{array}{l}\text { - Sebagian besar penduduk } \\
\text { memiliki mata pencaharian } \\
\text { yang terletak dekat atau di } \\
\text { Kampung Aur, sehingga jika } \\
\text { ada rencana relokasi hal ini } \\
\text { harus dipertimbangkan. }\end{array}$ \\
\hline $\begin{array}{l}\text { Keadaan } \\
\text { Banjir }\end{array}$ & 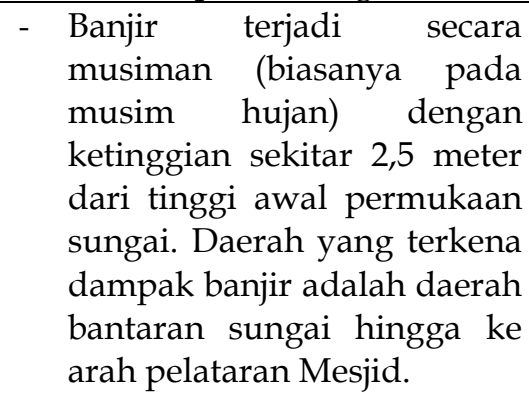 \\
\hline
\end{tabular}

\subsection{Kriteria Perancangan Permukiman Kampung Aur}

Dari hasil eksplorasi perilaku masyarakat terhadap setting unit hunian dan setting lingkungan serta analisa pendukung yang sudah dilakukan, maka didapatkan kriteria perancangan permukiman Kampung Aur sebagai berikut : (tabel 10, tabel 11, tabel 12)

Tabel 10 Kriteria Perancangan Permukiman Etnis Minang di Kampung Aur

\begin{tabular}{|l|l|l|}
\hline \multirow{2}{*}{$\begin{array}{l}\text { Komponen } \\
\text { Ruang }\end{array}$} & \multicolumn{2}{|c|}{ Kriteria Perancangan } \\
\cline { 2 - 3 } & Deskripsi Ruang & $\begin{array}{l}\text { Deskripsi } \\
\text { Perilaku }\end{array}$ \\
\hline Teras & - Pemilihan warna & - Perancang \\
& cerah untuk & an teras \\
& bagian luar dan & unit \\
& dalam ruangan & $\begin{array}{l}\text { hunian } \\
\end{array}$ \\
& & yang \\
& & dapat \\
& & mengako \\
\hline
\end{tabular}

\begin{tabular}{|c|c|c|}
\hline & & $\begin{array}{l}\text { modasi } \\
\text { melancark } \\
\text { an } \\
\text { terjadinya } \\
\text { interaksi } \\
\text { sosial }\end{array}$ \\
\hline $\begin{array}{l}\text { Ruang } \\
\text { Tamu / } \\
\text { Ruang } \\
\text { Keluarga }\end{array}$ & $\begin{array}{l}\text { - Penambahan } \\
\text { tempat } \\
\text { perletakan } \\
\text { perabotan / } \\
\text { barang yang } \\
\text { sifatnya } \\
\text { permanen dan } \\
\text { tidak } \\
\text { mengganggu } \\
\text { ruang yang ada } \\
\text { - Memaksimalkan } \\
\text { penghawaan } \\
\text { alami } \\
\text { - Memaksimalkan } \\
\text { pencahayaan } \\
\text { alami } \\
\text { - Pemilihan warna } \\
\text { cerah untuk } \\
\text { bagian luar dan } \\
\text { dalam ruangan } \\
\end{array}$ & $\begin{array}{l}\text { - Fleksibilit } \\
\text { as dalam } \\
\text { merancan } \\
\text { g ruang } \\
\text { - Tempat } \\
\text { perletakan } \\
\text { perabotan } \\
\text { tambahan } \\
\text { yang } \\
\text { sifatnya } \\
\text { permanen }\end{array}$ \\
\hline Dapur & $\begin{array}{l}\text { - Penambahan } \\
\text { tempat } \\
\text { perletakan } \\
\text { perabotan / } \\
\text { barang yang } \\
\text { sifatnya } \\
\text { permanen dan } \\
\text { tidak } \\
\text { mengganggu } \\
\text { ruang yang ada } \\
\text { - Memaksimalkan } \\
\text { penghawaan } \\
\text { alami } \\
\text { - Memaksimalkan } \\
\text { pencahayaan } \\
\text { alami } \\
\text { - Pemilihan warna } \\
\text { cerah untuk } \\
\text { bagian luar dan } \\
\text { dalam ruangan }\end{array}$ & $\begin{array}{l}\text { - Tempat } \\
\text { perletakan } \\
\text { perabotan } \\
\text { tambahan } \\
\text { yang } \\
\text { sifatnya } \\
\text { permanen } \\
\text { - Fleksibilit } \\
\text { as dalam } \\
\text { merancan } \\
\text { g ruang }\end{array}$ \\
\hline $\begin{array}{l}\text { Kamar } \\
\text { Mandi }\end{array}$ & $\begin{array}{l}\text { - Perbaikan } \\
\text { kondisi kamar } \\
\text { mandi } \\
\text { - Memaksimalkan } \\
\text { penghawaan } \\
\text { alami } \\
\text { - Memaksimalkan } \\
\text { pencahayaan }\end{array}$ & - \\
\hline
\end{tabular}




\begin{tabular}{|c|c|c|}
\hline & alami & \\
\hline $\begin{array}{l}\text { Kamar } \\
\text { Tidur }\end{array}$ & $\begin{array}{l}\text { - Memaksimalkan } \\
\text { pencahayaan } \\
\text { alami } \\
\text { - Memaksimalkan } \\
\text { penghawaan } \\
\text { alami }\end{array}$ & $\begin{array}{l}\text { - Pertambah } \\
\text { an jumlah } \\
\text { kamar } \\
\text { tidur juga } \\
\text { ditentukan } \\
\text { oleh ada } \\
\text { tidaknya } \\
\text { anak } \\
\text { perempuan } \\
\text { yang sudah } \\
\text { dewasa }\end{array}$ \\
\hline $\begin{array}{l}\text { Penambah } \\
\text { an Ruang } \\
\text { di Lantai } 2\end{array}$ & $\begin{array}{l}\text { - Penggunaan } \\
\text { material } \\
\text { permanen bila } \\
\text { ada penambahan } \\
\text { bangunan secara } \\
\text { vertikal } \\
\text { - Memaksimalkan } \\
\text { pencahayaan } \\
\text { alami } \\
\text { - Memaksimalkan } \\
\text { penghawaan } \\
\text { alami } \\
\text { - Pemilihan warna } \\
\text { cerah untuk } \\
\text { bagian luar dan } \\
\text { dalam ruangan }\end{array}$ & $\begin{array}{l}\text { - Perancanga } \\
\mathrm{n} \text { unit } \\
\text { hunian } \\
\text { yang dapat } \\
\text { mengakom } \\
\text { odasi } \\
\text { kemungkin } \\
\text { an } \\
\text { pertambah } \\
\text { an ruang } \\
\text { berdasarka } \\
\mathrm{n} \text { jumlah } \\
\text { anggota } \\
\text { keluarga } \\
\text { yang ada } \\
\text { - Fleksibilita } \\
\text { s dalam } \\
\text { merancang } \\
\text { ruang }\end{array}$ \\
\hline
\end{tabular}

Tabel 11 Kriteria Perancangan Permukiman Etnis Cina di Kampung Aur

\begin{tabular}{|l|l|l|}
\hline \multirow{2}{*}{$\begin{array}{l}\text { Komponen } \\
\text { Teras }\end{array}$} & \multicolumn{2}{|c|}{ Kriteria Perancangan } \\
\cline { 2 - 3 } & Deskripsi Ruang & $\begin{array}{l}\text { Deskripsi } \\
\text { Perilaku }\end{array}$ \\
\hline & $\begin{array}{l}\text { Pemilihan warna } \\
\text { cerah untuk } \\
\text { bagian luar dan } \\
\text { dalam ruangan }\end{array}$ & $\begin{array}{l}\text { Perancangan } \\
\text { teras unit } \\
\text { hunian yang } \\
\text { dapat } \\
\end{array}$ \\
& & $\begin{array}{l}\text { meningkatk } \\
\text { an interaksi } \\
\end{array}$ \\
& & sosial antar \\
& & tetangga \\
& & Perancangan \\
& & unit hunian \\
& & yang dapat \\
& & mengakomo \\
& & dasi \\
& & kebiasaan \\
& & merawat \\
\hline
\end{tabular}

\begin{tabular}{|c|c|c|}
\hline & & tanaman \\
\hline $\begin{array}{l}\text { Ruang } \\
\text { Tamu / } \\
\text { Ruang } \\
\text { Keluarga }\end{array}$ & $\begin{array}{l}\text { - Penambahan } \\
\text { tempat } \\
\text { perletakan } \\
\text { perabotan / } \\
\text { barang yang } \\
\text { sifatnya } \\
\text { permanen dan } \\
\text { tidak } \\
\text { mengganggu } \\
\text { ruang yang ada } \\
\text { - Pemilihan warna } \\
\text { cerah untuk } \\
\text { bagian luar dan } \\
\text { dalam ruangan }\end{array}$ & $\begin{array}{l}\text { Pembagian } \\
\text { fungsi ruang } \\
\text { yang jelas } \\
\text { Tempat } \\
\text { perletakan } \\
\text { perabotan } \\
\text { tambahan } \\
\text { yang } \\
\text { sifatnya } \\
\text { permanen } \\
\text { Perancangan } \\
\text { unit hunian } \\
\text { yang dapat } \\
\text { menjaga } \\
\text { privasi } \\
\text { penghuni }\end{array}$ \\
\hline Dapur & $\begin{array}{l}\text { - Penambahan } \\
\text { tempat } \\
\text { perletakan } \\
\text { perabotan } \\
\text { barang yang } \\
\text { sifatnya } \\
\text { permanen dan } \\
\text { tidak } \\
\text { mengganggu } \\
\text { ruang yang ada } \\
\text { - Memaksimalkan } \\
\text { penghawaan } \\
\text { alami } \\
\text { - Memaksimalkan } \\
\text { pencahayaan } \\
\text { alami } \\
\text { - Pemilihan warna } \\
\text { cerah untuk } \\
\text { bagian luar dan } \\
\text { dalam ruangan }\end{array}$ & $\begin{array}{l}\text { - Tempat } \\
\text { perletakan } \\
\text { perabotan } \\
\text { tambahan } \\
\text { yang } \\
\text { sifatnya } \\
\text { permanen }\end{array}$ \\
\hline $\begin{array}{l}\text { Kamar } \\
\text { Mandi }\end{array}$ & $\begin{array}{l}\text { - Memaksimalkan } \\
\text { penghawaan } \\
\text { alami } \\
\text { - Memaksimalkan } \\
\text { pencahayaan } \\
\text { alami }\end{array}$ & - \\
\hline $\begin{array}{l}\text { Kamar } \\
\text { Tidur }\end{array}$ & $\begin{array}{l}\text { - Memaksimalkan } \\
\text { pencahayaan } \\
\text { alami } \\
\text { - Memaksimalkan } \\
\text { penghawaan } \\
\text { alami }\end{array}$ & $\begin{array}{l}\text { - Perancangan } \\
\text { unit hunian } \\
\text { yang dapat } \\
\text { menjaga } \\
\text { privasi } \\
\text { penghuni }\end{array}$ \\
\hline
\end{tabular}

Tabel 12 Kriteria Perancangan Lingkungan di Kampung Aur

\begin{tabular}{c|c|}
\hline Komponen & Kriteria Perancangan \\
Lingkungan & \\
\hline
\end{tabular}




\begin{tabular}{|c|c|}
\hline Warung & 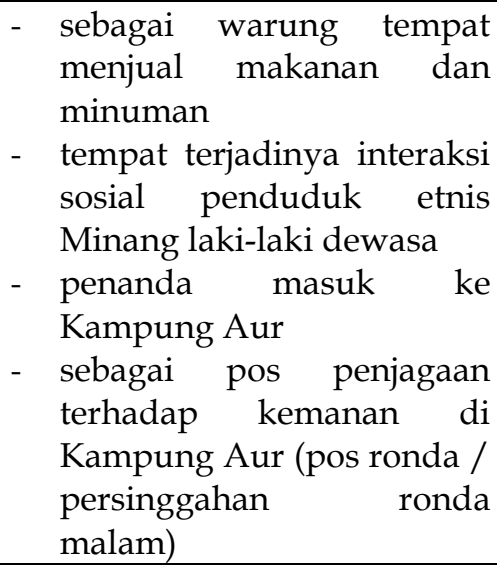 \\
\hline $\begin{array}{l}\text { Ruang } \\
\text { Terbuka } \\
\text { Anak }\end{array}$ & 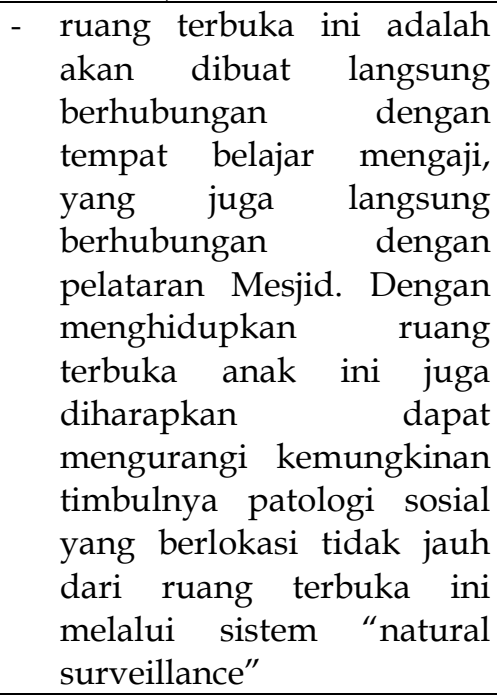 \\
\hline $\begin{array}{l}\text { Ruang } \\
\text { Terbuka } \\
\text { Umum }\end{array}$ & 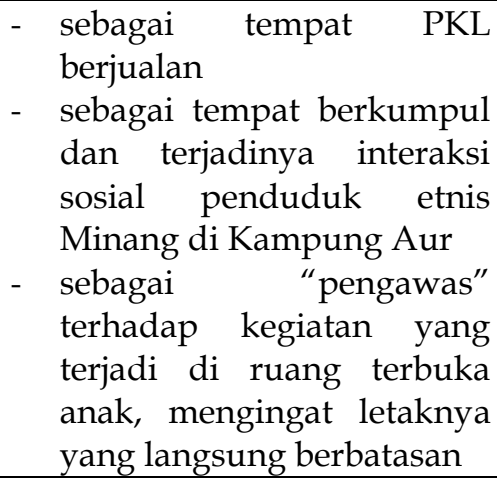 \\
\hline $\begin{array}{l}\text { Pelataran } \\
\text { Mesjid }\end{array}$ & 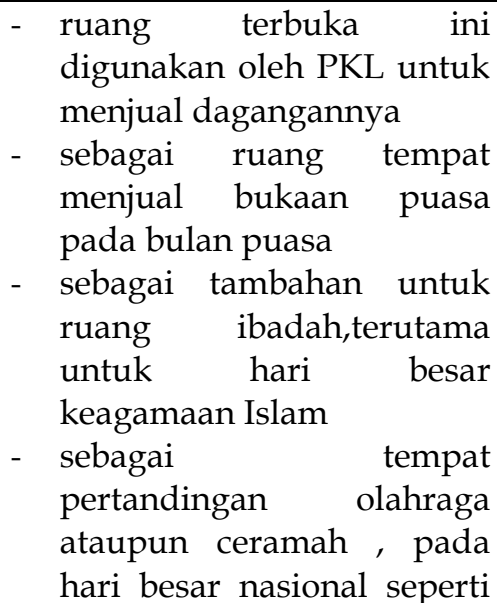 \\
\hline
\end{tabular}

\begin{tabular}{|c|c|}
\hline & hari kemerdekaan \\
\hline $\begin{array}{l}\text { Tempat Cuci } \\
\text { Bersama / } \\
\text { Bantaran } \\
\text { Sungai }\end{array}$ & 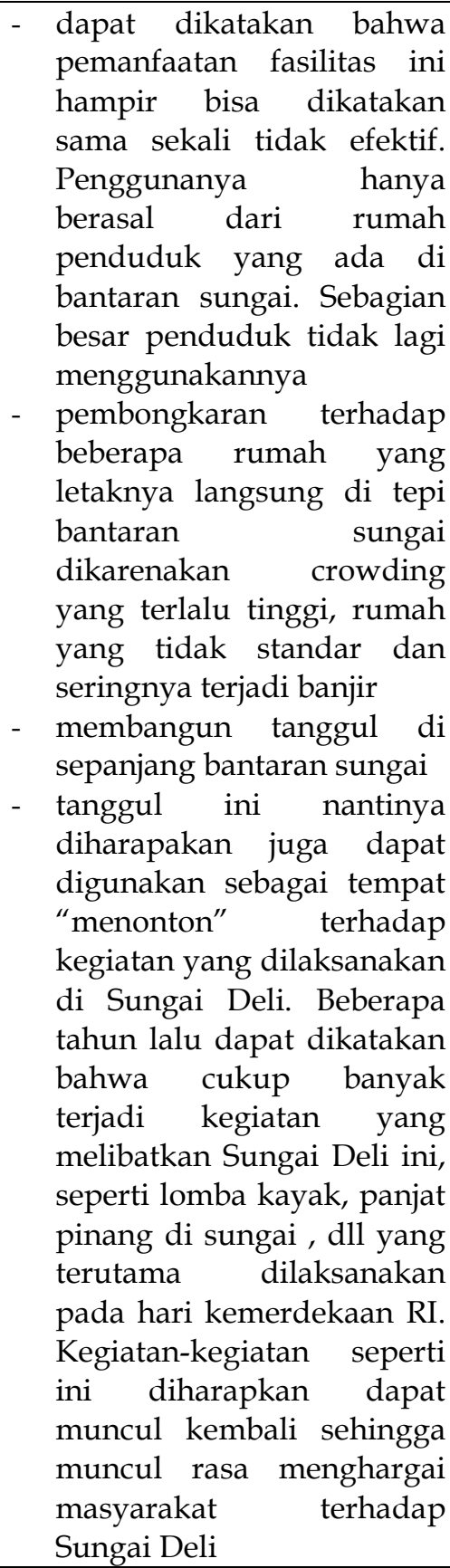 \\
\hline $\begin{array}{l}\text { Tempat } \\
\text { Jajanan } \\
\text { Malam }\end{array}$ & $\begin{array}{ll}\text { - } & \text { Penambahan tempat } \\
\text { jajanan malam di pelataran } \\
\text { ruko di Jalan Brigjend } \\
\text { Katamso }\end{array}$ \\
\hline \multicolumn{2}{|c|}{ Jalan (Sirkulasi) } \\
\hline $\begin{array}{l}\text { Jalan dengan } \\
\text { tingkat } \\
\text { keramaian } \\
\text { tinggi }\end{array}$ & $\begin{array}{ll}\text { - } & \text { sebagai tempat terjadinya } \\
\text { interaksi sosial di } \\
\text { masyarakat } \\
\text { - } \\
\text { sebagai tempat terjadinya } \\
\text { kegiatan ekonomi }\end{array}$ \\
\hline $\begin{array}{l}\text { Jalan dengan } \\
\text { tingkat } \\
\text { keramaian }\end{array}$ & $\begin{array}{l}\text { - menimbulkan interaksi } \\
\text { antar penduduk etnis Cina } \\
\text { dengan penduduk sekitar }\end{array}$ \\
\hline
\end{tabular}




\begin{tabular}{|l|l|}
\hline sedang & \\
\hline $\begin{array}{l}\text { Jalan dengan } \\
\text { tingkat } \\
\text { keramaian } \\
\text { rendah }\end{array}$ & $\begin{array}{l}\text { menerapkan kriteria desain } \\
\text { terjadinya tindak mencegah }\end{array}$ \\
\hline
\end{tabular}

\section{KESIMPULAN}

Adapun kesimpulan yang diperoleh dari penelitian yang sudah dilakukan antara lain :

a. Penduduk etnis Minang adalah kelompok penduduk yang sifatnya dinamis, memiliki tingkat interaksi sosial yang tinggi, mempunyai teritorialitas yang sangat tinggi dan tingkat privasi yang rendah. Dapat dikatakan karakter ini sama sekali tidak mencerminkan karakter penduduk kota besar pada umumnya, beberapa ahli mengatakan bahwa ini adalah karakteristik penduduk yang terdapat pada "Kampung Kota".

b. Penduduk etnis Cina sebaliknya memiliki karakteristik penduduk kota besar pada umunya, sifatnya individualistis, tingkat interaksi sosial yang rendah dan lebih banyak beraktivitas di luar rumah.

c. Terdapat 6 (enam) komponen lingkungan yang secara langsung mempengaruhi aktivitas / perilaku hidup masyarakat di Kampung Aur antara lain : (1) warung yang ada pada pintu masuk menuju Kampung Aur; (2) ruang terbuka umum yang digunakan terutama oleh orang dewasa untuk berkumpul; (3) ruang terbuka anak yang digunakan sebagi tempat bermain oleh anak-anak dan berdekatan dengan tempat pengajian; (4) ruang terbuka di Pelataran Mesjid yang terhubung langsung dengan bantaran sungai; (5) tempat jajanan malam; (6) serta karakteristik jalan berdasarkan lokasi dimana jalan tersebut berada

\section{Daftar Pustaka}

Haryadi dan Setiawan, 2014, Arsitektur, Lingkungan dan Perilaku. Yogyakarta : Gajah Mada University Press.

Rapoport, Amos, 1977, Human Aspect of Urban Form. Oxford: Pergamon Press. 